\title{
Animal Certifié Conforme: Déchiffrer nos Relations avec le Vivant
}

\author{
Bernadette Lizet and Jacqueline Milliet, eds. 2012. Dunod/Muséum National d'Histoire Naturelle, Paris. Pp 256. \\ $€ 22$ (paperback). ISBN 9782100582853.
}

Reviewed by Daniel W. Gade

Reviewer address: Department of Geography, University of Vermont, 94 University Place, Burlingtion, VT 05405. daniel.gade@uvm.edu

Received: December 1, 2013

Volume 5:13-14

Published: January 13, 2014

(C) 2014 Society of Ethnobiology

This collection of 11 unusually diverse essays converges on the theme of the uses and practices that humans have made of certain non-human creatures who share our planet. From microorganisms to mammals, the book captures a range of animals that humans have harnessed as food (seven cases), for companionship or aesthetic reasons (three cases), or as pests (one case).

Contributions on Microorganisms, Fish, and Insects

L. Bérard and M. C. Montel discussed the simplest organisms in this book, lactic bacteria, which form the indispensable element in making a cheese called salers. The only insect topic in the book was P. Blandin's thought provoking reflection on butterfly collecting as a hobby. P. Pellegrini and E. Rochard discussed fish in the Seine River, a stream benefitting from pollution control, but which still has the barrier of a hydroelectric dam to thwart fish migration upriver. S. Boulay and M. C. Cormier-Salem deal with another ichthyological theme off the coast of Mauri-tania where they described the flathead mullet (Mugil cephalus Linnaeus Mugilidae) and the uses to which that species has been put.

\section{Essays on Birds and Mammals}

Birds received attention in three chapters. R. Banchs, J. Braunstein, and D. Fournier wrote about the bluefronted parrot (Amazona aestiva Linnaeus Psittacidae) in the Chaco of Northern Argentina. Indians raid their nests in quebracho trees to capture the fledglings, which they sell to the international parrot trade. Intense collection of these psitticines, valued for their ability to talk, has become a conservation issue B. Lizet and J. Milliet described the practice in several municipalities in France that have, not without controversy, constructed public pigeon cotes as a way of keeping their numbers in check. A.M. Brisebarre presents the ins and outs of ostrich farming in France for meat as a problematic economic endeavor.

Mammals received attention in three chapters. F. Roy contributed an essay on how French sheepherders, who own no land, move their flocks in an ancient transhumance pattern between alpine pastures in summer and winter pastures near the Mediterranean coast. J. Riegel offered an assessment of the uneasy cohabitation of domestic cattle and wild buffalo in an ostensibly protected park in Western Niger. C. Harper and F. Bayart reported on the protective relationship that Sakalava people in Western Madagascar have with the black lemur (Eulemor macaco Linnaeus Lemuridae). Hunting them for food is restricted through the social pressure of a communal taboo $(f a d y)$, which functions to preserve these primates from extinction. A. E. Delavigne discoursed on no particular animal at all in his paper; instead, he explained the work of contemporary butchers. In spite of their name, they no longer actually kill livestock as they once did, a job that in France is relegated to slaughterhouses. The catchphrase "animal certifie conforme" used as the title of the book indicates commercial approval in the meat trade. The ironic intent of the editors may escape some readers who will be puzzled by the use of such a narrow title for such a diverse collection.

\section{Overall Evaluation}

Most of the authors of these 11 chapters are described as ethnologists, which would account for their interest in human adjustments more than in the animals themselves. Yet each chapter made a number of insightful points that provide a fresh perspective on the human-animal relationship. The well edited collection has few illustrations, though those included 


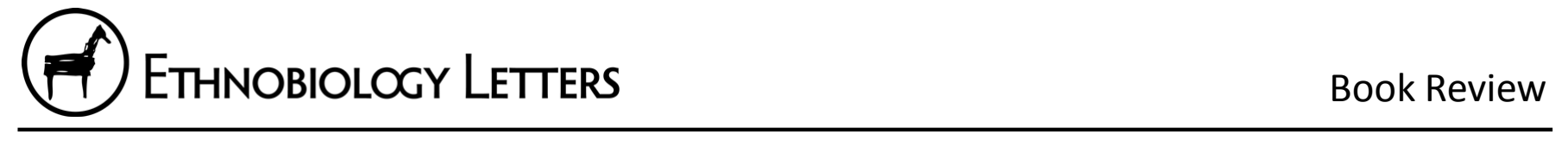

were carefully chosen. A substantial bibliography offers an entrée into some of the ethnozoological literature in French. Those who do not read French should at least be aware that by no means everything worth knowing in ethnobiology is in English. 